\title{
喉頭癌の三次元画像
}

\author{
桜 井一生・竹 内 健 二・加藤 久幸・門 山浩 \\ 宮城島 正 和・堀 部 晴 司・内 藤 健 晴
}

\section{Three-dimensional CT Images for Laryngeal Cancer}

\author{
Kazuo Sakurai, Kenji Takeuchi, Hisayuki Kato, \\ Hiroshi Kadoyama, Masakazu Miyagishima, Seiji Horibe \\ and Kensei Naito
}

In order to investigate the usefulness of three-dimensional CT images for assessment laryngeal cancer, we made multi-planar reconstruction (MPR) images and three-dimensional CT images using conventional helical $\mathrm{CT}$ and multi-slice $\mathrm{CT}$, and conducted imaging diagnoses of the developmental range of the cancer. Comparisons between convertional helical CT images and multi-slice CT images and with large specimens of the extracted larynx are reported here.

(1) MPR images were useful for diagnosis of the developmental range of laryngeal cancer, and the findings were almost identical to the analyses of the large specimens. Coronary and sagittal section images were particulary useful for diagnosis of cancer development in the superior and inferior directions in the glottis. Axial section images were useful for diagnosis of infiltration into the thyroid cartilage and the development to the extra-larynx.

(2) Multi-slice CT images improved the ability of spatial resolution over that of conventional helical CT images, and displayed the developmental range of tumors more clearly. The CT time was shorter and MPR images could be extracted while vocalizing, breathing at rest, and holding breath. Dynamic evaluation was possible.

(3) Imaging-facilitated understanding of the developmental-range of a tumor three-dimensionally. Multi-slice CT images were especially superior in the quality and three-dimensional condition.

Key words: 喉頭癌, 三次元画像, ヘリカル CT 画像

\section{1.はじめに}

1972年に CT が発表されて以来，昨今の CT 技術の革新 は目覚ましく鮮明な画像と多方面からの画像や三次元画像 が得られるようになり，その診断能力は大きく向上してき ている．喉頭領域においてもその有用性につきいくつかの 報告がなされている ${ }^{1 \sim 4)}$. 今回我々は喉頭癌症例に対する 三次元画像の有用性について検討するため, 従来のへリカ ル CT とマルチスライスヘリカル CT を用いた多断面再構 成像 (multiplanar reconstruction) と三次元 CT 像を作 製し喉頭癌の進展範囲の画像診断を行った。また, 従来の ヘリカル CT 像とマルチスライスヘリカル CT 像の比較な らびに摘出喉頭の大切片標本との比較検討を行ったので報 告する.

ヘリカル CT とは患者寝台を連続的に移動させながら， 高速かつ連続的に回転させ撮影を行う方法である ${ }^{5,6)}$. 検 出器が 1 例で 1 回転で 1 スライスのデータを収集するのが 従来のヘリカル CT であり, 複数の検出器列を有し, 1 回 転で複数のスライスデータを同時に収集するのがマルチス
ライスヘリカル CT（以下マルチスライス CT と略す）で ある7). 従来のへリカル CT やマルチスライス CTより得 られた三次元デー夕を撮影後に多断面に再構成したものが 多断面再構成像（以下 MPR 像と略す）であり，三次元に 再構成したものが三次元 CT 像である. 今回は喉頭癌症例 に対して従来のへリカル CT またはマルチスライス CT を 施行し, 得られたデータから MPR 像と三次元 CT 像を再 構成し,この両者を三次元画像として検討した.

\section{2. 対象症例}

対象症例は喉頭癌15症例で, 病理組織型はいずれも扁平 上皮癌であった，発生部位別には声門癌 7 例（T2 2 例, T3 3 例, T4 2 例), 声門上癌 7 例 (T2 4 例, T3 2 例, T4 1 例), Transglottis 1 例 (T4 1 例) であり, うち 3 例は放射線治療後の再発例であった。この15例中, 従来の ヘリカル CT にて検索した症例は声門癌 3 例, 声門上癌 4 例の計 7 例で, マルチスライス CT による検索例は声門癌 4 例, 声門上癌 3 例, Transglottis 1 例の計 8 例であっ た（表1）。 


\begin{tabular}{|c|c|c|c|}
\hline & T分類 & 従来のヘリカル CT & マルチスライス CT \\
\hline \multirow{3}{*}{ 声門癌 } & 2 & $1(1)$ & 1 \\
\hline & 3 & 1 & 2 \\
\hline & 4 & $1(1)$ & $1(1)$ \\
\hline \multirow{3}{*}{ 声門上癌 } & 2 & 2 & 2 \\
\hline & 3 & 1 & 1 \\
\hline & 4 & 1 & \\
\hline \multirow[t]{2}{*}{ Transglottis } & 4 & & 1 \\
\hline & & $7(2)$ & $8(1)$ \\
\hline
\end{tabular}

\section{3. 撮影装置ならびに撮影方法}

撮影装置は従来のヘリカル CT は東芝メディカル社製 TCT-900S, Xvigorを, マルチスライス CT は Aquilion を使用した。撮影条件は, TCT-900S, Xvigor では管電圧 $140 \mathrm{kV}$ ，管電流 $200 \mathrm{~mA} ， \mathrm{X}$ 線ビーム幅 $2 \mathrm{~mm}$ ，ローテーショ ンスピード 1 秒 $/ \mathrm{r}$, 寝台移動速度 $2 \mathrm{~mm} / \mathrm{r}$ と, Aquilion では管電圧 $135 \mathrm{kV}$, 管電流 $260 \mathrm{~mA}, \mathrm{X}$ 線ビーム幅 $1 \mathrm{~mm} \times$ 4 列, ヘリカルピッチ $3.5 \mathrm{~mm} / \mathrm{r}$ とした。撮影範囲は舌骨 から輪状軟骨までの約 $7 \mathrm{~cm}$ とし, 撮影時間は従来のへリ カル CTでは30秒, マルチスライス CTでは14秒とした。 造影剤は非イオン性ヨード造影剂を用いて, 従来のヘリカ ル CT では $300 \mathrm{mg} / \mathrm{ml}$ を $60 \sim 100 \mathrm{ml}$ 使用し, マルチスライ ス $\mathrm{CT}$ では $100 \mathrm{ml}$ を, インジェクターを用い $1.5 \mathrm{ml} /$ 秒で静 注した.

三次元画像処理に用いたワークステーションは, 従来の ヘリカル CT は Xtensionを, マルチスライス CT は ZioM900であった。

\section{4. 検 討 項 目}

検討項目は以下に示す項目とし, それぞれ摘出喉頭の大 切片標本との比較検討を行った。

1 ) MPR 像による喉頭癌の進展範囲の検索

·声門上下への進展

・ 甲状軟骨への浸潤

・喉頭外への進展

2 ) 従来のヘリカル CT 像とマルチスライス CT 像との 比較検討

3 ) 三次元 $\mathrm{CT}$ 像の検討

5. 結果

1 ) MPR 像による喉頭癌の進展範囲の検索

i ）声門上下への進展

腫瘍の声門上下への進展状態の検索には特に冠状断像, 矢状断像が有用であった。軸位断像では声門上下への進展 の有無については診断可能であったが, 進展範囲の検索は 特に進展範囲の少ない症例では診断が困難な症例が認めら れた。声門上下への進展状態の把握にMPR 像が特に有用 であった症例を呈示する。
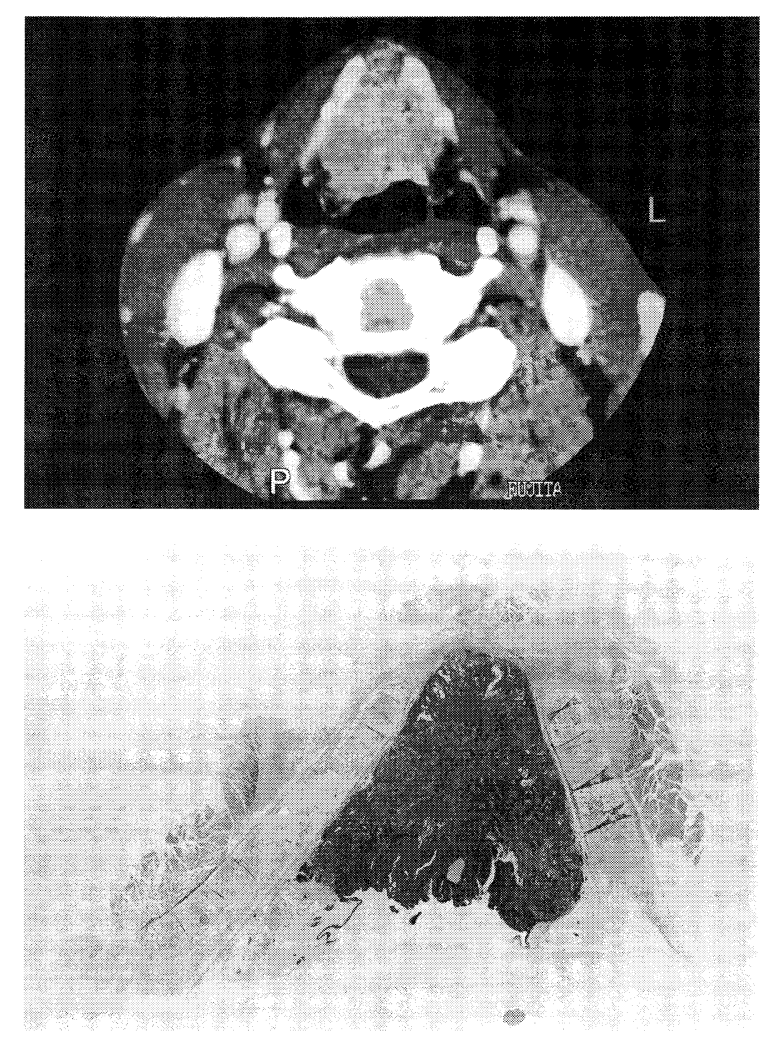

図 1 症例 1 声門上癌 $\mathrm{T} 2$

上：MPR 軸位断像（マルチスライス CT）

下：同部の大切片病理組織像

表 2 摘出喉頭の病理診断

\begin{tabular}{c|c}
\hline \hline 甲状軟骨浸潤 & 喉頭外進展 \\
\hline$(-) 5$ & $(-) 5$ \\
\hline$(+) 8$ & $(-) 3$ \\
& $(+) 5$ \\
\hline
\end{tabular}

症例 1。声門上癌 T2（図 1 )

症例 1 は舌骨下喉頭蓋喉頭面に隆起性病変を認めたが, 喉頭ファイバー所見では比較的浅在性病変と診断した。し かし, MPR 像では声門上部やや右側より preepiglottic spaceにかけて境界明瞭で均一な濃染をうける深在性の腫 瘍を認めた。MPR像は大切片標本の腫瘍の進展範囲とほ ぼ一致した所見であった。

ii ）甲状軟骨浸潤および喉頭外進展の検討

対象症例15例のうち喉頭全摘術を行った13症例について, 摘出喉頭の大切片標本を用いて病理組織学的に腫瘍の甲状 軟骨浸潤と喉頭外進展の有無について検討した。13例中甲 状軟骨浸潤を認めなかったものが 5 例で認めたものは 8 例 であり, 喉頭外進展については, 進展なし 8 例, 進展あり 5 例であった (表 2 ). 甲状軟骨浸潤があって喉頭外進展 のない症例すなわち腫瘍の進展が甲状軟骨内にとどまって いた症例が 3 例認められた。

次にMPR 像による甲状軟骨浸潤の診断を行い, 病理診 断との比較検討を行った. 尚, 今回の検討では MPR 像の 
表 3 MPR 像による甲状軟骨浸潤の診断

\begin{tabular}{c|c}
\hline \hline 病理診断 & MPR 診断 \\
\hline$(-) 5$ & $(-) 4$ \\
& $(+) 1$ \\
\hline$(+) 8$ & $(-) 3$ \\
& $(+) 5$ \\
\hline
\end{tabular}

表 $4 \mathrm{MPR}$ 像による喉頭外進展の診断

\begin{tabular}{c|c}
\hline \hline 病理診断 & MPR 診断 \\
\hline$(-) 8$ & $(-) 8$ \\
\hline$(+) 5$ & $(-) 1$ \\
& $(+) 4$ \\
\hline
\end{tabular}
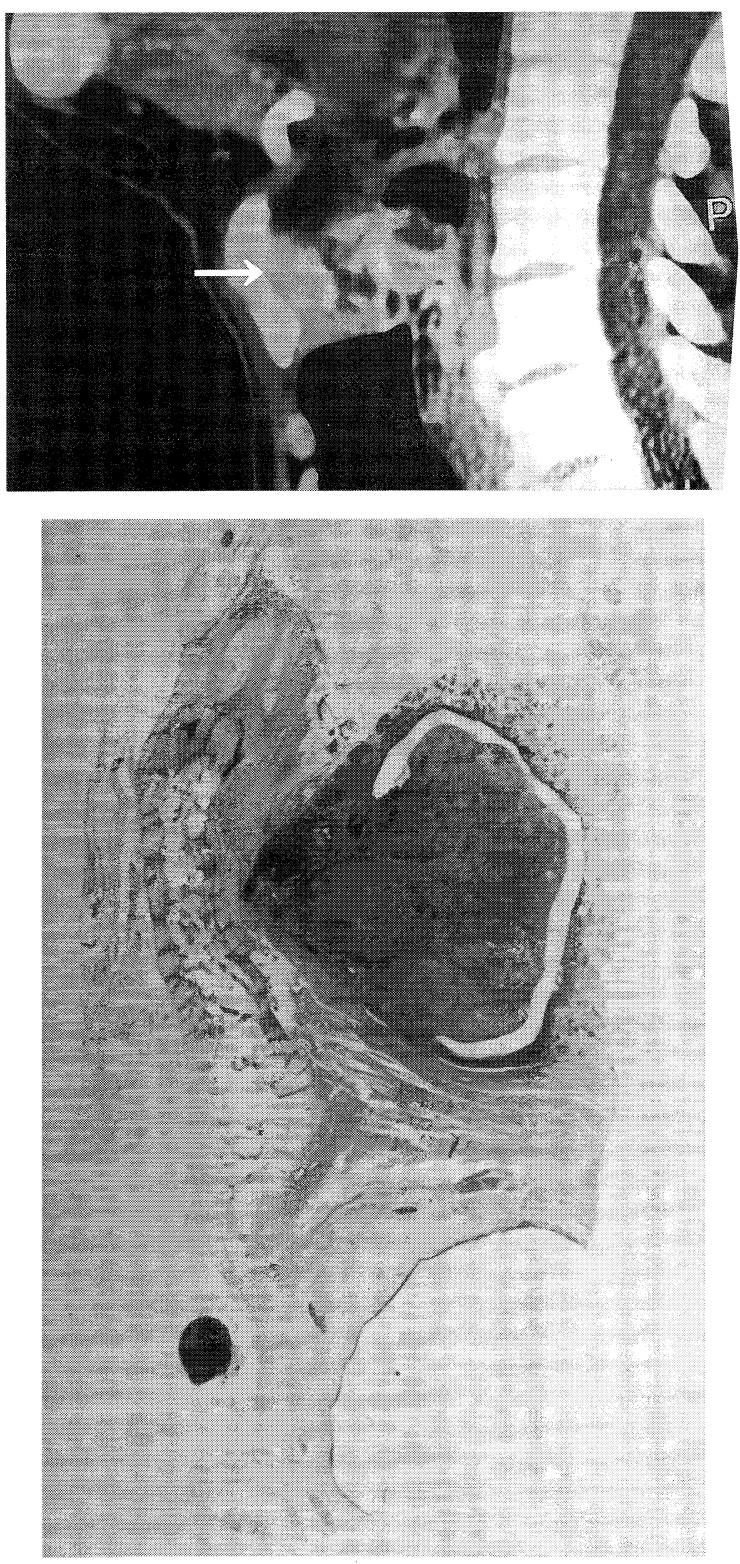

図 2 症例 2 声門癌 T2

上：MPR 矢状断像（マルチスライス CT)

(矢印：甲状軟骨内側壁の不整像)

下：同部の大切片病理組織像
診断は，術前に放射線科医が診断したものを用いた。病理 診断で甲状軟骨浸潤を認めなかった 5 例では，MPR 像で も甲状軟骨浸潤なしと診断した症例は 4 例で，正診率は 80 \%であった。病理診断で甲状軟骨浸潤を認めた 8 例では 5 例がMPR 像でも甲状軟骨浸潤ありと診断しており，正診 率は62.5\%であった（表 3 )。しかし，腫瘍の進展が甲状 軟骨内にとどまっていた 3 例中 2 例は，MPR 像で甲状軟 骨浸潤なしと診断しており，その正診率は $33.3 \%$ と低率で あった。

喉頭外進展については，病理診断で喉頭外進展を認めな かった 8 例はすべて MPR 像でも喉頭外進展なしと診断し ており，正診率は100\%であった。病理診断で喉頭外進展 を認めた 5 例では，4例はMPR 像で喉頭外進展ありと診 断しており，正診率は80\%であった（表 4)。喉頭外進展 をきたした症例の多くは甲状軟骨の破壊を伴っており，こ のような症例の MPR 像での診断は比較的容易であった。 次に病理診断で甲状軟骨浸潤を認めず，MPR 像で甲状軟 骨浸潤ありと診断した症例 2 ，病理診断で甲状軟骨浸潤な しと診断した症例 3，MPR 像で喉頭外進展が診断できな かった症例 4 を呈示する。

症例 2。声門癌 T2（図 2 ）

症例 2 は，前連合部から両側声带，喉頭室にかけて浸潤 する腫瘍を認めた。 MPR 像では，矢状断像にて腫瘍の接
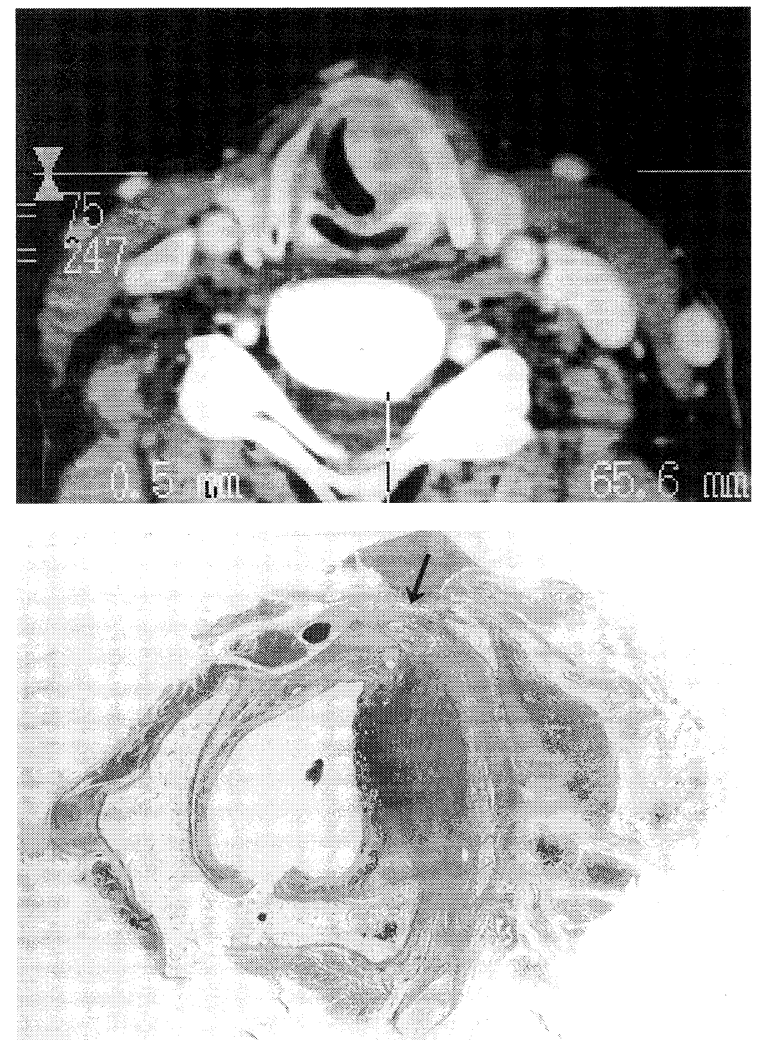

図 3 症例 3 声門上癌 $\mathrm{T} 2$

上：MPR 軸位断像（従来のへリカル CT） 下：同部の大切片病理組織像 (矢印：甲状軟骨への浸潤部) 
する甲状軟骨内側壁の不整が認められ，甲状軟骨浸潤あり と診断した.しかし，大切片標本では腫瘍は甲状軟骨内に は浸潤しておらず，この症例のように甲状軟骨内側壁が不 整に抽出される例では, 診断が困難と思われた。

症例 3 . 声門上癌 $\mathrm{T} 2$ (図 3 )

症例 3 は, 軸位断像で腫瘍が接する部位での甲状軟骨内 壁には不整はなく, 甲状軟骨浸潤なしと診断したが，大切 片標本では腫瘍は甲状軟骨内に浸潤しており，このような 微小な浸潤例の診断は困難であった.

症例 4 . 声門上癌 $\mathrm{T} 2$ (図 4 )

症例 4 は, MPR 像で preepiglottic spaceへ進展した
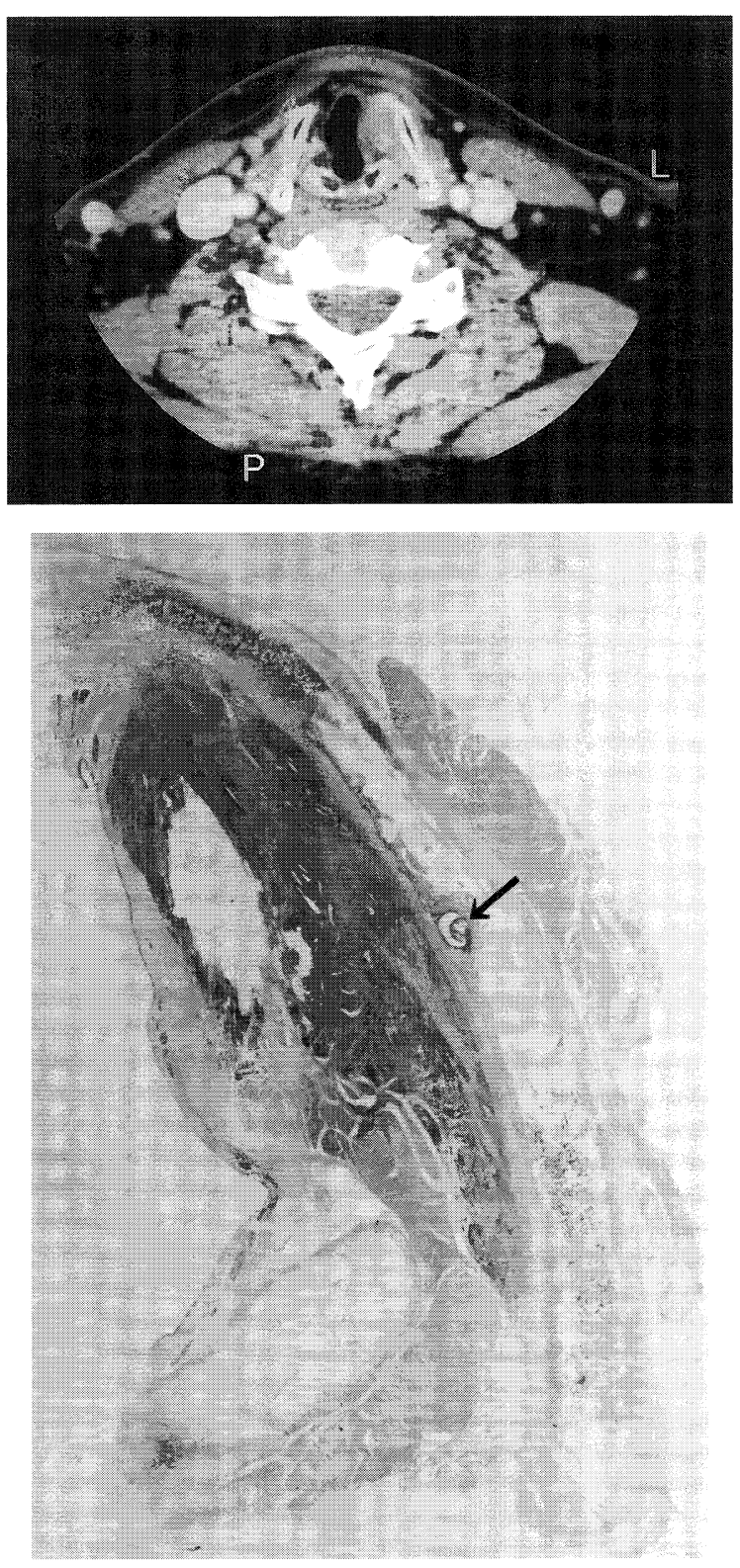

図 4-A 症例 4 声門上癌 $\mathrm{T} 2$

上：MPR 軸位断像（マルチスライス CT）

下：同部の大切片病理組織像

(矢印：甲状軟骨への浸潤部)
腫瘍を認めるが甲状軟骨への浸潤はなく, 喉頭外進展なし と診断した。しかし，大切片標本では小さな甲状軟骨浸潤 と甲状軟骨と輪状軟骨間から喉頭外へ進展した腫瘍を認め た。この症例のような軟骨の破壊を伴わない小範囲の喉頭 外進展例の診断は困難と思われた。

2 ) 従来のヘリカル CT 像マルチスライス CT 像との比 較検討

従来のヘリカル CT 像（図 3 ）とマルチスライス CT 像 （図 1，2，4）を比較すると, 両者とも腫瘍の進展範囲 は大切片標本とほぼ一致していたが, マルチスライス CT 像では，空間分解能が向上し，画像が鮮明となり，腫瘍の
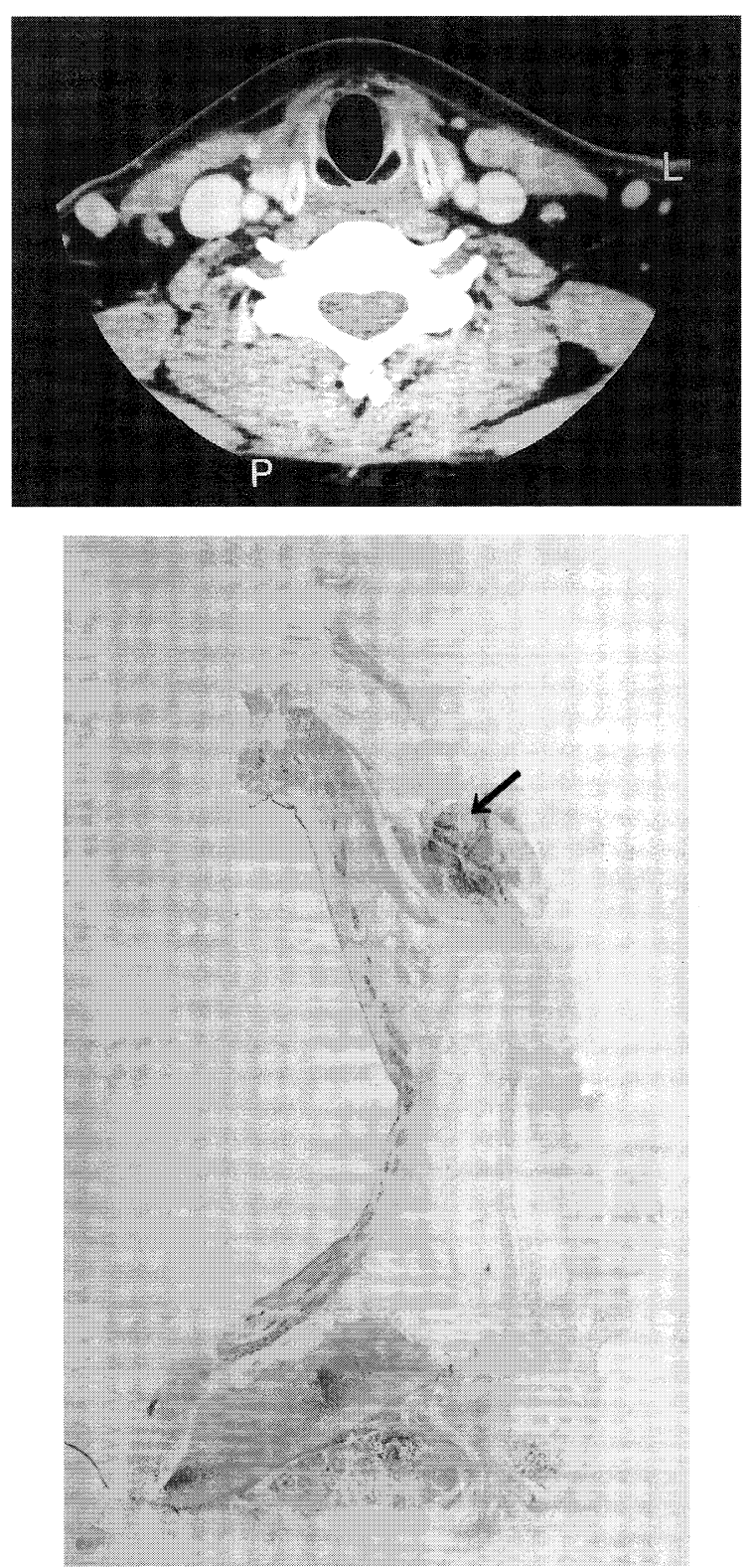

図 4-B 症例 4 声門上癌 $\mathrm{T} 2$ 上：MPR 軸位断像 (マルチスライス CT) 下：同部の大切片病理組織像 （矢印：㑨頭外進展部） 
境界がより明瞭であった。

また, 撮影時間が 14 秒と短くなり, 安静呼吸時, 発声時, 息止め時の撮影が可能となり, 声帯運動の動的評価も可能 となった. 放射線治療後に腫瘍が消失し, 声帯運動の回復 がMPR 像にて確認できた症例 5 を呈示する。

症例 5 .声門癌 T3（図 5 )

症例 5 は左声帯から喉頭室にかけて浸潤する腫瘍で, 治 療前には左声帯は固定していた.MPR冠状断像で, 声門 から声門上部にかけてほほ均一に造影される腫瘍を認め,
安静呼吸時, 発声時, 息止め時のいずれでも左声帯は同様 に抽出されており，声帯が固定しているのが確認できた。 治療後の MPR 像では腫瘍は消失し, 安静呼吸時, 発声時, 息止め時の声帯の状態の違いより, 声帯運動も回復してい るのが確認できた。

3 ) 三次元 CT 像による検討

従来のヘリカル CT による三次元 CT 像を図 6 に示した. 症例 6 は甲状軟骨を破壊し喉頭外へ進展した T4症例で, 腫瘍の進展範囲は大切片標本とほぼ一致しており, 腫瘍の

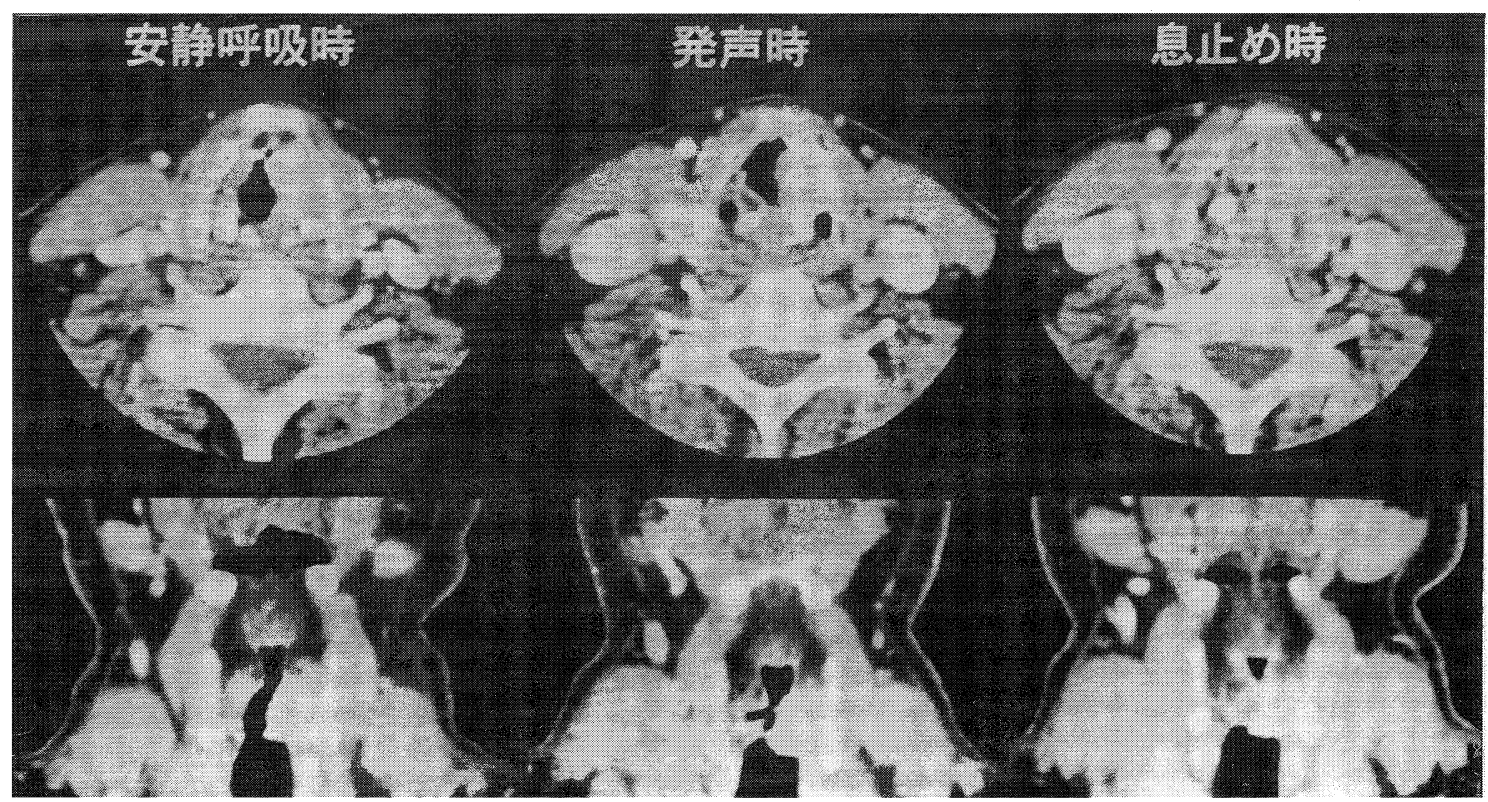

放射線治療前

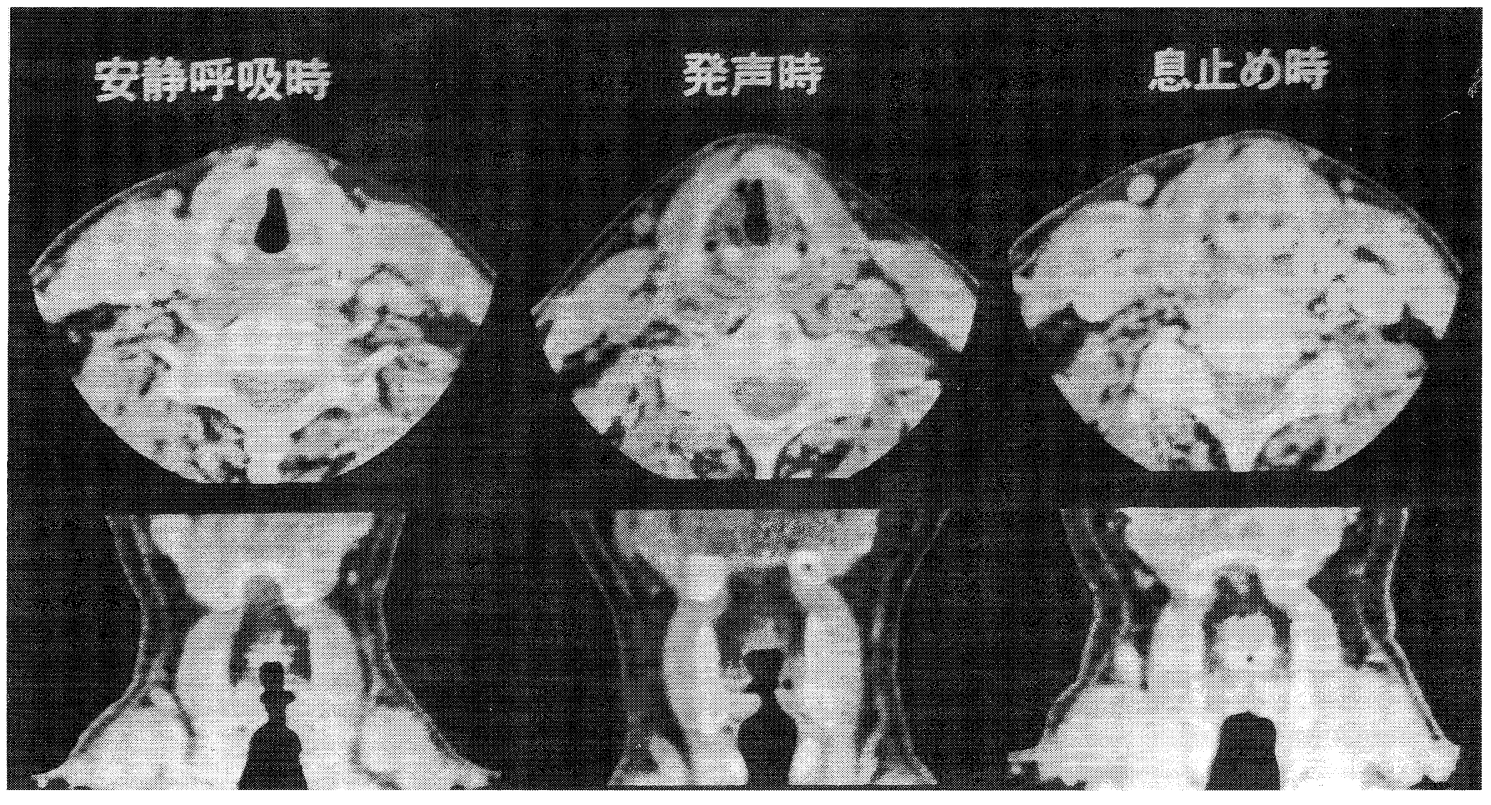

放射線治療後

図 5 症例 5 声門癌 T3

上段：MPR 軸位断像（マルチスライス CT $)$

下段：MPR 冠状断像（マルチスライス CT) 

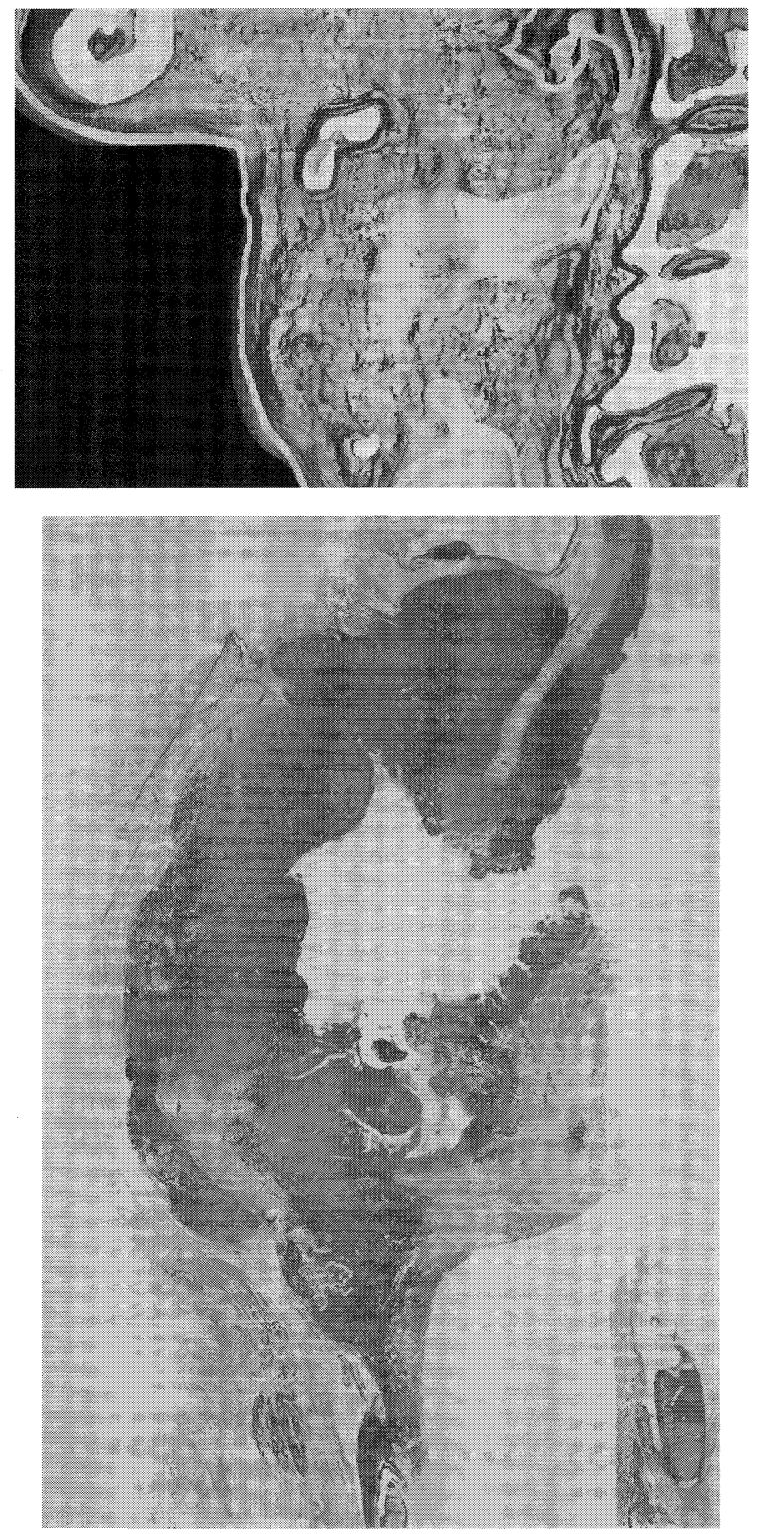

図 6 症例 6 Transglottis T4 上：従来のヘリカル CT での三次元 CT 像 下：大切片病理組織像

進展範囲の立体的把握が容易となった。しかし，従来のへ リカル CTではしきい值により，色づけを行うため腫瘍と 同等のしきい值を示す部分が同色となり，腫瘍の境界が不 明暸であった。マルチスライス CTでの三次元 CT 像を図 7 に示した。症例 7 は声門上癌 $\mathrm{T} 2$ 症例である。マルチス ライス CTではデー夕収集後, 例えば，皮膚，軟部組織， 造影された腫瘍, 血管, 骨, 軟骨というょうにある一定範 囲内のしきい值内にある臟器別に画像を作製し，後からそ れぞれの画像を組み合わせることができ，臓器別の色分け も可能となった。従ってより腫瘍の境界が鮮明となり，従 来のへリカル CT 像と比べて，より質感，立体感に優れた 画像を得ることができた。
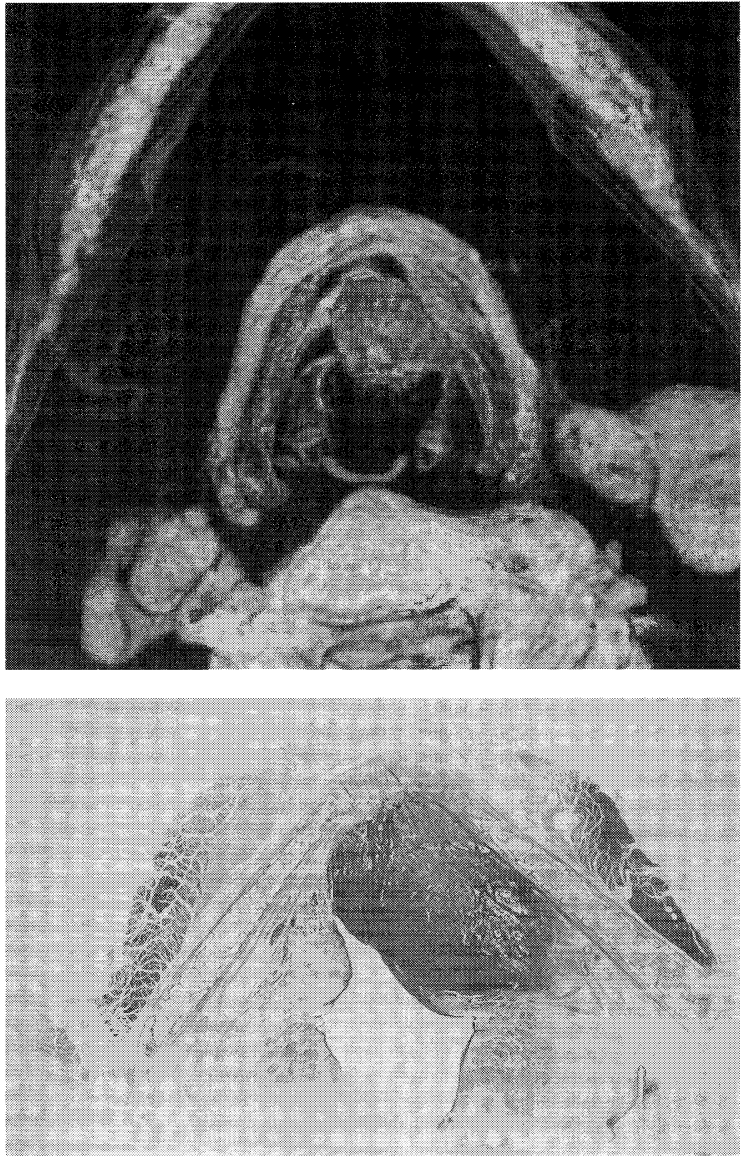

図 7 症例 7 声門上癌 $\mathrm{T} 2$ 上：マルチスライス CT での三次元 CT 像 下: 大切片病理組織像

6. 考

察

喉頭癌は間接喉頭鏡や喉頭ファイバースコープにより視 診が可能であり, 特に声带運動制限のない早期例では前連 合部へ浸潤する症例以外では CT 検査の有用性は少ないも のと思われる。一方, 進行癌では特に声門上下への進展, 喉頭外進展の有無は，切除範囲の決定やリンパ節郭清の範 囲の決定に必要な検査と考える ${ }^{3)}$. 従来の CT では呼吸や嚥 下運動によるモーションアーチファクトが問題となり，鮮 明な画像が得られにくく, 詳細な検討が困難なことも少な 〈なかっだ). しかし，ヘリカル CT ではスキャン休止時間 がないため, 従来の CT と比べ検査時間が短く, しかもデー 夕の体軸方向の連続性が良く, モーションアーチファクト の影響が少なくなり, 鮮明な画像が得られるようになった 特にMPR像から得られる情報はより鮮明，詳細となり喉 頭癌の術前検査としての有用性も増加したものと思われる. 今回, 自験例でヘリカル CT から得られた MPR 像と摘出 喉頭の大切片標本とを比較検討したが，腫瘍の浸潤範囲は 両者でほぼ一致しており，信頼できる情報となったと考え る。特に最近開発されたマルチスライス CTでは，その画 像はより鮮明となり，術前診断に極めて有用と思われた。 
特に声門上下への進展に対しては冠状断像, 矢状断像が, 甲状軟骨浸潤, 喉頭外進展に関しては軸位断像が有用であっ た。しかし，甲状軟骨と腫瘍との関係は腫瘍が軟骨を破壊 し, 喉頭外へ進展している例や腫瘍が軟骨と接していない 例では，診断は比較的容易であったが，腫瘍が軟骨に接し ている症例での軟骨への腫瘍の浸潤の有無の診断は難しく, 特に軟骨内に腫瘍が滞まった 3 症例の診断率は $33.3 \%$ と低 率であり，腫瘍が接する部位の軟骨壁が不整に抽出される 例での診断は困難であり，現在のところマルチスライス CTを用いても限界があるものと思われた．

従来のヘリカル CT とマルチスライス CT 像とを比較す ると, マルチスライス CT 像は, より空間分解能にすぐれ, 腫瘍の境界が鮮明となった。また, 撮影時間の短縮により, 発声時, 息止め時, 安静呼吸時, それぞれの画像が得られ, 声帯運動の動的評価も可能となり，放射線治療により腫瘍 が消失し，声帯運動が回復した症例を画像の上でも確認す ることができた。このことは, 喉頭癌の術前, 術後の声帯 運動の検討のみならず, 喉頭麻疩, 披裂関節脱臼等の疾患 の診断や病態の把握, 術後経過の観察等にも有用になるも のと考える ${ }^{4,9)}$.

三次元 $\mathrm{CT}$ 像は，従来より我々は複数の CT 值域に異な る色と透明度を設定することにより，いくつかの組織を三 次元に分離カラー表示する三次元カラー表示を行ってき た ${ }^{10)}$. 三次元カラー表示では腫瘍の前喉頭蓋間隙や傍喉頭 間隙への進展が明瞭に抽出され，大切片標本での腫瘍の進 展範囲とほぼ一致した所見であった。

また，腫瘍やその周囲組織との解剖学的な位置関係の理 解が容易となり有用であった。しかし，空気と接する臓器 表面や内腔はパーシャルボリウム効果により, 均一な表面 構造物として抽出され，腫瘍や粘膜表層と空気層の境界は 明瞭に認識できなかった。また，グレースケール表示に比 し8色という少ない段階に色分けをするため, コントラス トの差が少ない筋層と腫瘍との境界は抽出困難であった ${ }^{11)}$. 一方, マルチスライス CT では, モーションアーチファク 卜の発生がほとんどなく，デー夕収集後，ある一定範囲内 のしきい值にある臓器別に画像を作製し，色分けした後か らそれぞれの画像を組み合わせることが可能となった. 従っ て, より腫瘍の境界が鮮明となり進展範囲の立体的把握が 容易となり，より有用であった。しかし，画像作製にはい くつかの処理過程の結果できあがる画像の客観性や再現性 の問題等まだ多くの課題があり, 実用にはさらなる改善が 必要と思われた。

\section{7.まと め}

・喉頭癌の進展範囲の診断における三次元画像の有用性に ついて摘出喉頭の大切片標本と比較検討した。

・MPR 像は腫瘍の進展範囲の診断には極めて有用であっ た。

・甲状軟骨浸潤の診断はマルチスライス CT 像を用いても, 現在のところ限界があるものと思われた。

・マルチスライス CT では声帯運動の動的評価も可能となっ た。

・ 三次元 CT 像は腫瘍の浸潤範囲の立体的把握が容易であっ たが，実用にはさらなる改善が必要と思われた。

参 考 文 献

1）山本智矢ほか：喉頭疾患の三次元画像解析. 喉頭 6:109 116, 1994.

2）上田隆志ほか：三次元画像について一喉頭領域一. 日気食認定医通信 $15 ： 3 \sim 5,1997$.

3）上村裕和ほか：3-DCT による喉頭癌進展の診断一摘 出喉頭と対比して一。頭頸部腫瘍 $26 ： 557 \sim 566$, 2000.

4）湯本英二ほか：喉頭の CT 内視像一ヘリカル CT の応 用一。 日気食会報 $49: 71 \sim 77,1998$.

5）片田和廣：ヘリカルスキャン CT一その原理と特徵— 日画像医誌 $12 ： 127 \sim 137,1991$.

6）安野泰史ほか：ヘリカルスキャン CTの基礎研究一体 軸方向の空間分解能の評価一。日医放線会誌 52 ： 1540 1544， 1992

7）加藤良一ほか：マルチスライス CT の臨床．癌の臨床 $46: 1039 \sim 1051,2000$.

8）藤井直子ほか：へリカル CT. JOHNS 12： $1237 \sim 1251,1996$.

9）讃岐徹治ほか：正常および喉頭疾患における三次元 CT 内視法の応用. 耳喉頭頸 $69 ： 211 \sim 216,1997$.

10）岩田重信：画像診断一へリカル CT 三次元画像一. 喉頭癌．日気食会報 $100 ： 358 \sim 361 ， 1997$.

11）加藤久幸：頭頸部領域の三次元 CT 診断の有用性に 関する研究. 藤田学園医学会誌. 学位論文集 19 ： $1 \sim 28,2000$.

別刷請求先 テ 470-1192 豊明市沓掛町田楽ケ窪1-98 藤田保健衛生大学医学部耳鼻咽喉科学教室

桜井一生 